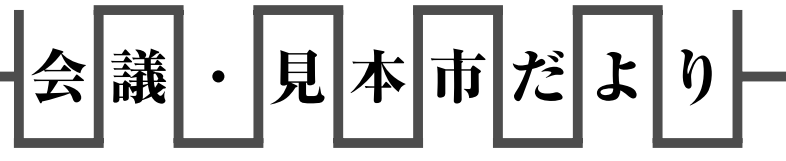

\section{SAE 2003}

神 成 貴 晴*·熊 谷 勝 久*

地球の温暖化が世界的な問題となっている昨今, その原 因となる二酸化炭素の発生主原因の一つとされている自動 車に対しての風当たりの厳しくなっている時期に開催され た, 自動車業界の技術発表・展示会である.「より速く, より便利で，居心地の良い」ということだけに重点をおい たこれまでの自動車開発ではなく, これらの要求にさらに

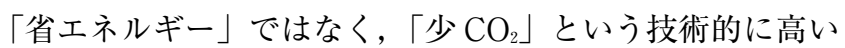
目標が掲げられた自動車開発の将来に対しての展示やセッ ションが予想された. 実際この展示会を前にして, 米国 GM 社がハイブリッド車の販売計画と燃料電池車の試作車を発 表, 日本国内各カーメーカーも次世代のエネルギーとして 水素を用いた燃料電池試作車の公道試験を開始している.

このような技術開発の進展に伴い, 樹脂部品の開発につい ても大きく期待される環境となってきている.

以上のような状況の中, SAE 2003 が 2003 年 3 月 3 日 から 7 日の間アメリカ合衆国ミシガン州デトロイト市の Cobo Centerで開催された。メイン会場となったCOBO ホールでは本年 1 月には北米国際自動車ショー (NAIAS : North American International Automotive Show）も開催 されており, 外気温が 0 度を下回る中, SAE 展示会場内 には多くの関係者が訪れ活況を呈していた。

今回の展示は以下の 5 つの主要なテーマに基づき開催さ れた (写真 1,2$)$.

1. Advanced Propulsion/Power train（最新推進・動力 機構)

2. Advanced Electronics（最新電子技術）

3. Environment/Emissions（環境・排出）

4. Safety/Testing (安全性・試験)

5. Lightweight Materials（軽量素材）

$\mathrm{SAE}$ というとアメリカ，ヨーロッパの企業を中心とし た企業展示会というイメージがこれまでは強かったが, 東 南アジアや中国, その他の地域でも自動車が交通手段とし てごく普通に使用されるなど, 自動車産業のグローバル化

\footnotetext{
* Kannari, Takaharu/Kumagai, Katsuhisa

日本ジーイープラスチックス侏 $、$ マーケティング本部

自動車用途応用技術開発部

P.O. Box 5011 Southfield, MI 48086

2003.3.24 受理
}

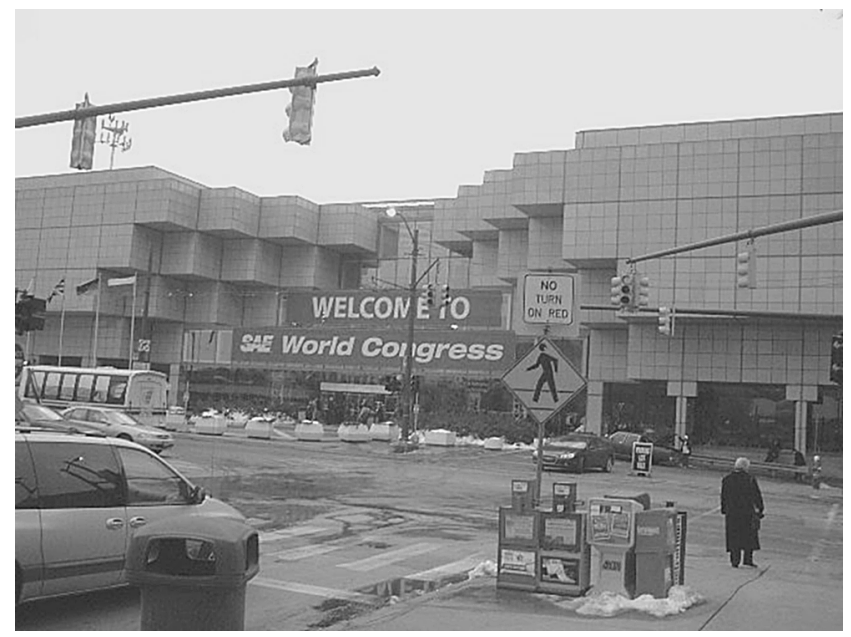

写真 1 会場外観

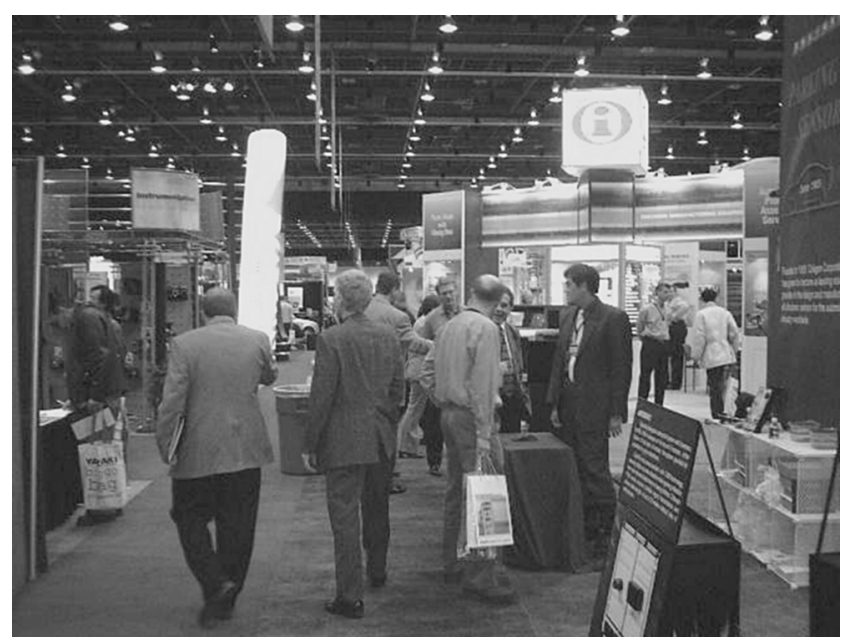

写真 2 多くの各国の人々が見学に

に伴い, SAEも国際色を強くしている. 今回の展示会に おいても展示会会場には上記の 5 つのテーマに関連する参 加企業の展示に加え，オーストリア，中国，韓国，トルコ， メキシコなど 12 か国がそれぞれの地域の企業による製 品・技術紹介, ならびに政府関連組織による企業誘致プロ グラムに関する展示を行っていた（写真 $3 ， 4$ ）。

\section{Advanced Propulsion/Power train}

まず，あたらしい動力としては，日本では自動車での動 


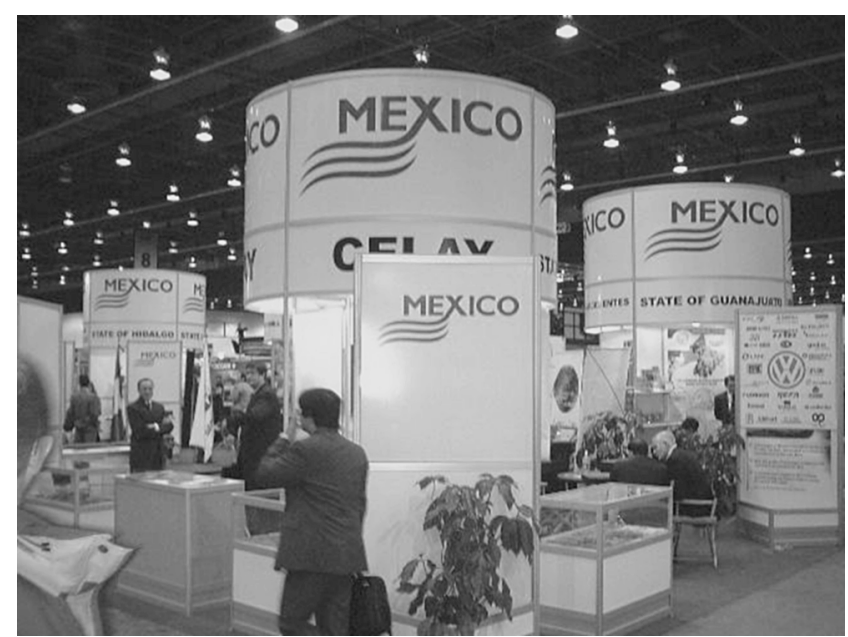

写真 3 各国の展示ブース 1

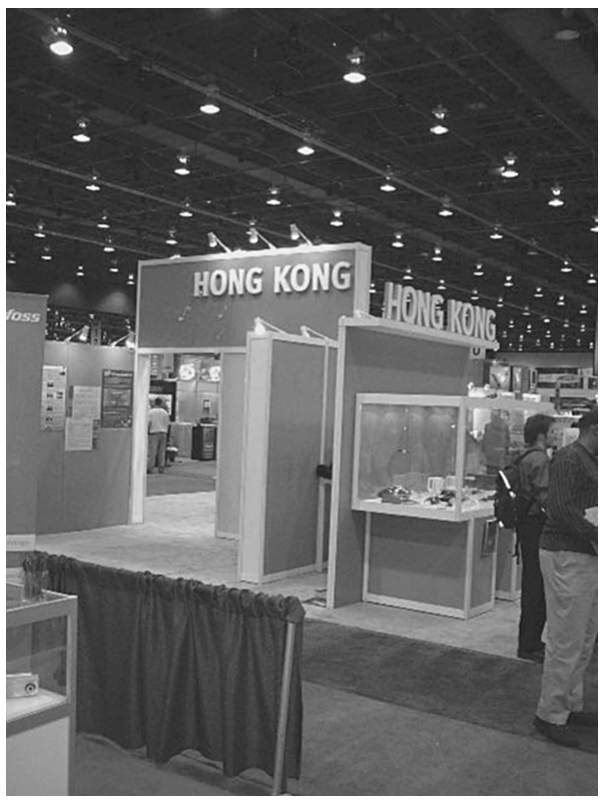

写真 4 各国の展示ブース 2

力革命とされている燃料電池，ハイブリッド関連の開発が 進められているのだが, 燃料電池車の本格的な生産は 2010 年と見られている. 先日もこれまで然料電池などの開発を 行なっていながら，量産車に対しての発表を控えていた $\mathrm{GM}$ 社が，ハイブリッド車の開発計画とプラットフォーム 型燃料電池駆動ユニットをベースとする燃料電池車のコン セプト車を披露し，本格的な低公害車の開発の全貌をしめ した。

一方，欧州の傾向としては，より現実的に二酸化炭素の 発生がガソリンエンジンょり少なくかつ低ランニングコス 卜を実現できるディーゼルエンジンの人気が高い．また， 水素エンジンの開発を行なっているカーメーカーもある. このような各地域，カーメーカー各社の開発ポリシーの多 様性に伴い, 今回のセッションにおいても, 従来のディー ゼルエンジンやガソリンエンジンの効率化に関するものと ハイブリッドや燃料電池に関する発表が混在していた。 ハ イブリッド車両の生産に打いては, 日系カーメーカーが先 行しているものの, こうした先進低二酸化炭素排出を目ざ したパワートレインの開発は, 今後熾烈な開発競争を呈す
るものと考えられ, 軽量化の必要性の下に部品の樹脂化や セラミック化も進むものと考えられる.

\section{Advanced Electronics}

日本国内ではナビゲーターの装着率がかなり進み，ETC (自動料金システム) のほか，防犯システムや事故の際の 自動通報システムなどが次々と商品化されている。これま では，走行するための電子制御，もしくは緊急停止のため の電子制御（ABS な゙）が主体となり自動車の電子化は 進んできた。しかし，インターネットの普及とそれに伴う IT (Information Technology) の発達が, 自動車の電子機 器化を大きく進化させようとしている，そのような背景で の今回の展示における最新電子技術のセッションは, これ までのハードのみのものだけではなく, 電子機器をオぺ レーションするためのソフトウェアにも視点を置いたもの も散見された。

\section{Environment/Emissions}

当該セッションは，現状のマイナーチェンジ的なものか ら将来を見据えるようなものまで幅広いものと予想された のだが，実際には，現状のガソリンエンジンの低公害化と， 昨今 PM（微粒子物質）問題が大きく取り上げられている ディーゼルエンジンの低公害化に関するものが中心であっ た。欧州ではその経済性から害に新車販売でも同エンジン 搭載車種が 3 割以上を占める。これは経済性以外にディー ゼルエンジンが，ガソリンエンジンに比較して二酸化炭素 の発生量が低いためとも思われた。このような点からも ディーゼルエンジンに関する欧米各企業の関心の高さがう かがえた。

\section{Safety/Testing}

15 年ほど前までは, 自動車の安全性の商品価值として の位置づけは，現在に比べると低いものだったと記憶して いる. しかし，シートベルト装着，エアバッグの装着，ア ンチロックブレーキの標準装備化などから始まった各種の 安全装備は，いまとなっては側方からの衝突に対しての カーテンエアバッグ装着にまで進化してきた。このような ことから安全性は自動車の商品価值の一つとなっていると 言える．さらに，欧州では 2005 年から歩行者に対しての 自動車の安全性評価を公表することが明らかになっている. 日本国内に打いてもこの動きに追随する形で同様の試験は 準備されている.

今回のセッションには，これまでのホイールやサスペン ション，エアバッグといった自動車部品についての検討の 他，CAE と呼ばれるコンピューターシュミレーションに よる衝突解析や乗員の損傷解析に関するものが含まれてい た。ささらにすでに日本でも検討されている，より現実に 近い仮想空間の実現という点から, 人間工学的な切り口か ら自動車内の運転者の安全性を検討するセッションなども あった. 自動走行システムなどを目指した開発の中で, 運 転者の様々な運転中の行動やそこに起因する事故などが研 究されており，そのような事故の発生を防ぐハードやソフ トの検討が行なわれている. 


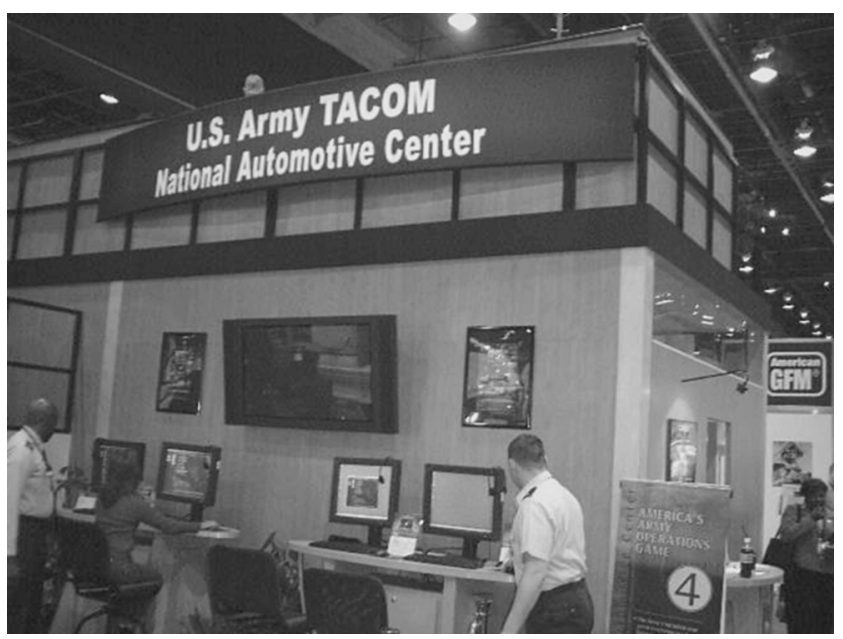

写真 5 展示会場内風景

\section{Light weight Materials}

今回のセッションでもっとも樹脂拉よび樹脂加工に関係 する内容が含まれていたのは，この軽量素材に関するセッ ションであった。軽量化は, 省エネルギー化と地球温暖化 の原因となる二酸化炭素の排出を抑えるという視点から， 各カーメーカーの大目的のひとつとなっている。「3リッ ター・カー」の開発をヨーロッパでは進めており, すでに 日本ではハイブリッド・カーでほぼその目的值に近い燃焼 消費率を達成できるものが量産されている. 地球温暖化に 対しての一般消費者の認識が高まるに従い，各社の軽量化 への取組みはますます熱を帯びてきている. 軽量化の方法 としては, 軽金属類やセラミックおよび樹脂の使用による 鉄部品などの置換えが考えられている. 今回のセッション においても内装, 外装それぞれに樹脂使用例の発表が行な われていたが，今回は新規の技術として目新しい物はな かった。これはすでに，日本国内では比較的低比重のポリ プロピレンの使用が広がっており，通常の射出成形以外に， インモールド加飾，ブロー成形などの中空成形などが行な われ，最近は溶着を利用した構造インスツルメントパネル 等が使用されている.また, 従来は大部分が金属部品であっ たフロント部分やドア部分が，モジュールとしての設計が され, 素材としてガラス瀻維強化樹脂が使用された樹脂性 の, フロントエンド・モジュールやドア・モジュールの例も ある. 今後, 進められる軽量化の対象である空ガラスの樹 脂化については, 今回の SAEでは特別なセッションは組 まれてはいなかった。

世界各社の提携関係が複雑にはりめぐらされ, 部品調達 に関しても従来の地域調達が世界調達となってきている今, 部品メーカーや素材メーカーは, 国際的な価格競争にさら される状態となっており，その中で競争力をつけるための 開発を行なう必要が高くなっているようである. 各社の ブースの展示からも, 開発能力と品質の高さを示すような 展示がめだった。また，コストダウンの手法の一つとして，

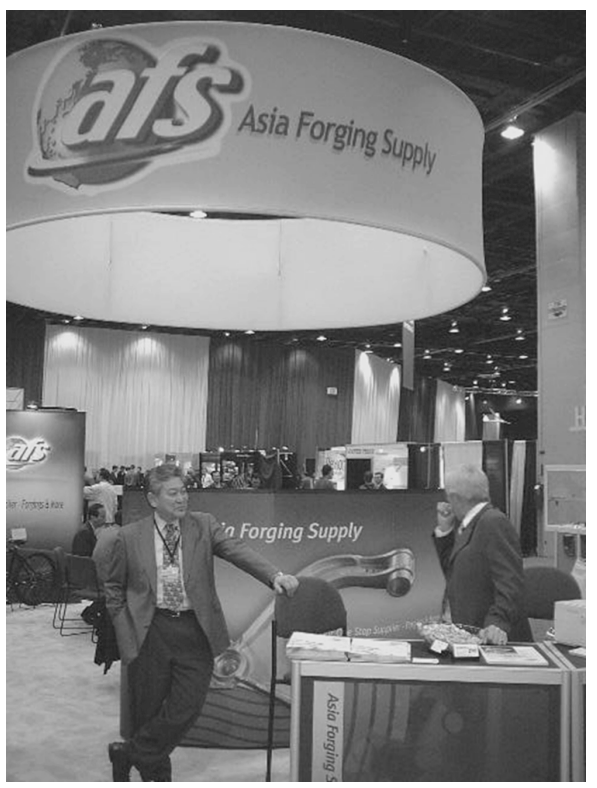

写真 6 展示会場内風景

コンピューターシミュレーションが挙げられるが，これま での加工用に使用されてきた CAD, CAE が樹脂製部品の 設計, 加工などに使用されるようになり, このような手法 が多用されて一貫的開発が進むと予想され，加工技術にお けるこのような手法の開発の遅れが懸念された。これから の自動車生産, 特に生産量の多い小型中型車両の生産は, 日本や韓国, SEA（東南アジア）および中国が中心とさ れている. 特に中国ではこの数年内に急激なモータリゼー ションが訪れるのではないかと考えられ, 自動車産業各社 は中国での生産拠点を設けることに躍起となっている.

各社の本格的な生産が進むとともに, 中国の国産カー メーカーもこれらの海外カーメーカーの技術を習得し, 自 国での自動車生産をはじめようとしている，中国および SEA のマーケットは欧米に匹敵する規模であり, 欧米各 地域でほぼ飽和状態になっている自動車生産の活性化に貢 献する事は明らかである (写真 6)。さらに, 中国, SEA のマーケットが本格的に購買力をつけるのは数年後の 2005 年ごろからと考えられる. その頃の開発傾向として は，二酸化炭素の発生を抑えたハイブリッド車や新型の ディーゼルエンジンが主流となり, 燃料電池車も本格的な 生産が始まると見られている時期に合致するものと考えら れる. 現時点ではそのような社会での自動車の価值観が, 一般の消費者にとってどのように測られているか予測し 難い.

しかしながら，今後の自動車産業の技術革新はさらに発 展的で, 製造業の各種技術の集約となる性質からも一層注 目を集めていくものと予想される. 今後の SAEにおいて は, 新しい車づくりや安全面により注目した社会システム づくりに対する様々な提案, 展示の場を提供していくもの と予想され，その動向には注目していきたい. 